\title{
A flyway perspective of foraging activity in Eurasian Green-winged Teal, Anas crecca crecca
}

\author{
C. Arzel, J . Elmberg, and M. Guillemain
}

\begin{abstract}
Time-activity budgets in the family Anatidae are available for the wintering and breeding periods. We present the first flyway-level study of foraging time in a long-distance migrant, the Eurasian Green-winged Teal, Anas crecca crecca L., 1758 ("Teal"). Behavioral data from early and late spring staging, breeding, and molting sites were collected with standardized protocols to explore differences between the sexes, seasons, and diel patterns. Teal foraging activity was compared with that of the Mallard, Anas platyrhynchos L., 1758 and Northern Shoveler, Anas clypeata L., 1758, and the potential effects of duck density and predator-caused disturbance were explored. In early spring, foraging time was moderate $(50.5 \%)$ and mostly nocturnal (45\%). It increased dramatically in all three species at migration stopovers and during molt, mostly because of increased diurnal foraging, while nocturnal foraging remained fairly constant along the flyway. These patterns adhere to the "income breeding" strategy expected for this species. No differences between the sexes were recorded in either species studied. Teal foraging time was positively correlated with density of Teal and all ducks present, but negatively correlated with predator disturbance. Our study suggests that Teal, in addition to being income breeders, may also be considered as income migrants; they find the energy necessary to migrate at staging sites along the flyway.

Résumé : Les budgets-temps des Anatidae sont disponibles pour les périodes d'hivernage et de reproduction. Nous présentons la première étude, à l'échelle d'une voie de migration, du temps d'approvisionnement d'un migrateur de longue distance, la sarcelle d'hiver, Anas crecca crecca L., 1758. Les données comportementales de début et fin de migration printanière, reproduction et mue ont été obtenues, avec le même protocole, afin de tester les différences entre sexes, saisons et variations nycthémérales. L'approvisionnement des sarcelles est comparé à celui des canards colverts, Anas platyrhynchos L., 1758, et des canards souchets, Anas clypeata L., 1758; les effets de la densité de canards et du dérangement par les prédateurs sont également testés. Au début du printemps, le temps d'approvisionnement était court (50,5\%), et essentiellement nocturne (45\%). Il augmentait ensuite de façon spectaculaire pour les trois espèces sur les haltes migratoires et durant la mue (principalement à cause de l'approvisionnement diurne, l'approvisionnement nocturne étant constant). Ceci s'accorde avec la stratégie de « reproducteur sur revenu » attendue chez ces espèces. Aucune différence inter-sexe n'a été relevée chez les espèces étudiées. Le temps d'approvisionnement des sarcelles était corrélé positivement avec leur densité et celle de l'ensemble des canards présents et négativement avec le dérangement par les prédateurs. Les sarcelles seraient des reproducteurs mais également des migrateurs sur revenu, trouvant l'énergie nécessaire à leur migration en route.
\end{abstract}

\section{Introduction}

An animal's energy requirements are influenced by shortterm variations in biotic and abiotic conditions, but many species also tune their biological cycle to regular and more dramatic annual variations (King 1974). Accordingly, during some periods of the year individuals may have to increase their energy intake to meet particular needs, such as those linked to migration and reproduction (King 1974; Ricklefs 1974). Time-activity budgets have long been an essential instrument to use for approaching questions about daily energy needs, and thereby also assessing evolutionary hypotheses about behavior and potential bottlenecks in the annual cycle. Moreover, time-activity budgets are a basic yet powerful general tool in the study of wild populations, since an understanding of a species' behavioral requirements is a prerequisite for proper management (e.g., Sutherland and Gosling 2000). Finally, recent advances in the development of behavior-based individual models of population dynamics highlight the importance of understanding basic behavior prior to initial model parameterization (e.g., Pettifor et al. 2000; Stillman et al. 2000). Given the general and multiple values of time-activity budgets, they are particularly relevant for management and conservation of, and pol-

Received 4 August 2006. Accepted 28 November 2006. Published on the NRC Research Press Web site at http://cjz.nrc.ca on 17 February 2007.

C. Arzel. ${ }^{1}$ Centre National d'Étude et de Recherche Appliquée en Avifaune Migratrice, Office National de la Chasse et de la Faune Sauvage, La Tour du Valat, Le Sambuc, F-13200 Arles, France; Department of Mathematics and Natural Sciences, Kristianstad University, SE-29188 Kristianstad, Sweden; Laboratoire d'Écologie des Hydrosystèmes, Université Paul Sabatier, 118 route de Narbonne, F-31062 Toulouse, France.

J. Elmberg. Department of Mathematics and Natural Sciences, Kristianstad University, SE-29188 Kristianstad, Sweden.

M. Guillemain. Centre National d'Étude et de Recherche Appliquée en Avifaune Migratrice, Office National de la Chasse et de la Faune Sauvage, La Tour du Valat, Le Sambuc, F-13200 Arles, France.

${ }^{1}$ Corresponding author (e-mail: celine_arzel@yahoo.fr). 
icy-making for, harvested species. Among hunted birds, ducks (family Anatidae) are the most important game worldwide, and they have long been focal organisms in wildlife ecology. However, even for the best studied duck species, significant gaps remain in the understanding of time use, especially from a circumannual perspective (see review in Arzel et al. 2006).

Within the Anatidae, time-activity budgets of dabbling ducks (Anas spp.) have mainly been documented for either wintering (Tamisier 1972; review in Paulus 1982; Miller 1985; Morton et al. 1989) or breeding birds (e.g., Seymour 1974; Asplund 1981; Åström 1992). Time use in staging spring-migrating dabbling ducks remains almost undocumented, even in very common and otherwise well-studied species (but see Arzel and Elmberg 2004). This is a crucial and remarkable knowledge gap, not only in itself, but also because many previous avian studies indicate that behavioral choices and trade-offs made in spring are likely to affect subsequent breeding success and thus the fitness of individuals (Paulus 1982; Teunissen et al. 1985; Baldassarre et al. 1988; Alisauskas and Ankney 1994; Ebbinge and Spaans 1995; Lindberg et al. 1997; Arzel 2006). Ideally, time use by migratory species should be studied with standardized methods year-round. To our knowledge there is only one such study of dabbling ducks (Hickey and Titman 1983), but it was carried out in a limited geographical area and, unfortunately, mixes data from resident birds with those from transient migratory birds.

In any time-budget study of a migratory species, the fact that fat and protein reserves that individuals carry may influence subsequent behavior needs to be considered (see Thompson and Raveling 1987). In other words, the reserves a bird is able to acquire at a stopover site and then carry through the subsequent flying episode can influence behavior, for example how much time is allocated to foraging, at the next stopover (King 1974). Indeed, if a bird still has enough reserves when arriving at a stopover site it may rest rather than feed (Guillemain et al. 2004), which may explain why behavior does not necessarily reflect the foraging opportunities at a study site. This income-expenditure time lag is yet another reason why it is important to study a species throughout its migratory journey and throughout its flyway.

The Eurasian Green-winged Teal (Anas crecca crecca L., 1758 (hereinafter "Teal") is one of the smallest duck species. According to the theory of capital versus income breeding, it is thus expected to be an income breeder, i.e., it cannot store enough energy on wintering grounds to cover the costs of migration and subsequent egg laying (see the American Green-winged Teal, Anas crecca carolinensis L., 1758 (Gmelin, 1789), in Paquette and Ankney 1998; Klaassen 2002). Teal are therefore expected to make several stopovers along the migration route to forage and restore energy reserves. Theoretically, the most efficient scenario for Teal is to arrive at the breeding grounds in such good condition that minimum time is needed to secure the protein and lipids necessary for rapid clutch formation and egg laying, as earlier nesting pairs have greater reproductive success (Elmberg et al. 2005). Consequently, it can be hypothesized that the condition in which birds arrive at breeding grounds affects their time use there, and hence the date of egg laying, and hence breeding success. The latter may therefore be deter- mined partly by environmental conditions along the flyway and during migration, and partly by those on the breeding grounds.

The aim of the present study was to address the shortcomings described above by recording Teal behavior at a variety of sites within several regions throughout a flyway over 2 years. Using strictly standardized methods we studied ducks from February to August, covering the premigration, staging, breeding, and molting phases of the annual cycle. Specifically, we set out to answer the following questions:

(1) What is the general diel pattern of foraging time from premigration to molting?

(2) Does daily foraging time change over time within a period of the year (hereinafter "season") or region? For example, does the time spent foraging increase from a bird's arrival until its departure from each region?

(3) Are there differences between the sexes in diel foraging patterns?

(4) Does the time devoted to foraging by Teal differ from that of cooccurring Northern Shoveler, Anas clypeata L., 1758 (hereinafter "Shoveler"), and Mallard, Anas platyrhynchos L., 1758 ?

(5) Does the density of co-occurring congeners and the level of predator disturbance influence daily foraging time of Teal?

\section{Methods}

\section{Study areas}

The Western European flyway of Teal is rather well defined; the results of studies based on ringing recoveries (Koskimies 1956; Solonen 1985; Scott and Rose 1996; Fransson and Pettersson 2001; Wernham et al. 2002; Bakken et al. 2003) agree that many Teal wintering in France migrate to breeding grounds in Scandinavia, Finland, and western Russia. For the present study we selected five regions within this flyway, all known to be highly attractive to dabbling ducks in general and Teal in particular (see below). The study sites are used by premigrating, staging, breeding, and molting birds whose behavior we studied in FebruaryJuly 2003 and February-August 2004 (Table 1).

\section{Marais Vernier}

Guillemain et al. (2006) showed that Teal depart from wintering habitats in southern France as early as early February. Birds studied in February and March in northern France are thus mainly transient migrants, but at the beginning of the annual study period there were also some locally wintering individuals present. In the Marais Vernier region $\left(49^{\circ} 29^{\prime} \mathrm{N}, 0^{\circ} 07^{\prime} \mathrm{E}\right)$ we selected two sites forming a wider unit: at the Grand'Mare reserve we sampled behavior during daylight hours (0600-1800), while the Legay pond was used at night (1800-0600). The Grand'Mare reserve is one of the most important Teal day roosts in the area (Clairefond and Schricke 1994), but here, as in many other French wintering and spring-staging areas, ducks leave at dusk for nearby nocturnal foraging sites (cf. Tamisier and Dehorter 1999). One of them is the Legay pond, which is surrounded by a grazed pasture and located only $1400 \mathrm{~m}$ from the Grand'Mare reserve. The fact that the latter is the major day roost in the area supports the assumption that the same birds used 
Table 1. Numbers of Eurasian Green-winged Teal (Anas crecca crecca) scan samples per year, region, month, season, and period of the day.

\begin{tabular}{llllll}
\hline & & & & \multicolumn{2}{l}{ Period of the day } \\
\cline { 5 - 6 } Region & & & & Diurnal & Nocturnal \\
Marais Vernier & 2003 & February & Esm & $39(4)$ & \\
& 2003 & March & Esm & $49(5)$ & \\
& 2004 & February & Esm & $30(3)$ & $12(1)$ \\
Norvik & 2004 & March & Esm & $28(4)$ & $21(4)$ \\
Vinnö & 2003 & April & Lsm & $35(4)$ & $8(4)$ \\
Brånsjön & 2004 & April & Lsm & $90(8)$ & $20(7)$ \\
& 2003 & May & Lsm & $66(6)$ & $25(6)$ \\
& 2003 & June & B & $16(4)$ & $36(3)$ \\
& 2003 & July & B & $11(3)$ & $15(3)$ \\
& 2004 & May & Lsm & $24(5)$ & $14(3)$ \\
& 2004 & June & B & $37(5)$ & $36(5)$ \\
Breeding lakes & 2004 & July & B & $38(4)$ & $20(4)$ \\
& 2004 & August & M & $19(2)$ & $11(2)$ \\
& 2003 & June & B & $32(2)$ & $19(2)$ \\
& 2003 & July & B & $55(3)$ & $21(3)$ \\
& 2004 & June & B & $9(1)$ & $3(1)$ \\
& 2004 & July & B & $41(4)$ & $2(2)$ \\
& 2004 & August & M & $1(1)$ & \\
\hline
\end{tabular}

Note: Numbers in parentheses show the number of sampling days (Esm, early spring migration; Lsm, late spring migration; $\mathrm{B}$, breeding; $\mathrm{M}$, molting).

both sites. For convenience, "Marais Vernier" will be used throughout to represent both these study sites.

\section{Southern Sweden}

Two regions represented conditions and behavior roughly halfway along the migration route. In April 2003 we used 15 ha of the Norvik coastal lagoon $\left(56^{\circ} 42^{\prime} \mathrm{N}, 16^{\circ} 42^{\prime} \mathrm{E}\right)$ in the Ottenby nature reserve on Öland Island in the Baltic Sea, an area hosting large numbers of waders and waterfowl at the time of sampling. In April 2004 we used the alluvial pastures at Vinnö Ängar $\left(56^{\circ} 01^{\prime} \mathrm{N}, 1^{\circ} 09^{\prime} \mathrm{E}\right.$; hereinafter "Vinnö") in the province of Scania. The 1.5 ha area studied is part of a complex of wetlands and seasonally flooded meadows internationally recognized as an important stopover area for waders and waterfowl (Kristianstads Vattenrike UNESCO Biosphere Reserve).

\section{Västerbotten}

Prebreeding and breeding ducks were studied at 12 lakes in the Umeå area $\left(63^{\circ} 49^{\prime} \mathrm{N}, 20^{\circ} 16^{\prime} \mathrm{E}\right)$ in the province of Västerbotten, north-central Sweden, from May to July 2003 and from May to August 2004. Eleven of them are typical boreal breeding lakes for Teal, i.e., they are small (0.57 ha), oligotrophic, and surrounded by coniferous forest, and have shores dominated by floating peat bog (chiefly the genus Sphagnum L.). In 2003, we studied Teal behavior at 10 lakes, but in 2004 only 6 of them had breeding Teal, which is why another lake was added to the sample that year. The 12th lake, Brånsjön, is much larger (32 ha), eutrophic, surrounded by cereals and hayfields, and located in an open agricultural landscape. Brånsjön Lake is part of a nature reserve used by thousands of dabbling ducks as a staging site in spring, and by hundreds for breeding and molting (e.g., Sjöberg 1986).

\section{Guild composition}

During the study, all sites except the 11 oligotrophic breeding lakes were used by all seven dabbling duck species breeding in Western Europe: Teal, Mallard, Shoveler, Eurasian Wigeon (Anas penelope (L., 1758)), Gadwall (Anas strepera (L., 1758)), Garganey (Anas querquedula (L., 1758)), and Northern Pintail (Anas acuta (L., 1758)). Teal and Mallard were the most abundant species everywhere. Garganey and Northern Pintail were sparse and rarely occurring in all regions, while Shoveler, Eurasian Wigeon, and Gadwall were more or less common depending on the region. Teal were often the only dabbling ducks on the breeding lakes; a habitat in which Mallard and Eurasian Wigeon are the only other widespread breeding dabblers (e.g., Danell and Sjöberg 1979). We studied foraging behavior in Mallard and Shoveler as well, to compare with that of Teal because the former two species are relatively abundant in most regions studied and share much of the latter species' diet. In other words, Mallard and Shoveler were the most likely putative competitors with Teal.

\section{Behavioral observations}

From hides or observation towers, we used the scan-sampling method (Altmann 1974) to record the behavior of each dabbling duck visible on a wetland. The observer remained in the hide all day to minimize disturbance. All data were recorded by the same observer (C.A.). In both years we sampled behavior throughout all daylight hours (cf. Table 1). Twenty-four-hour sampling was possible in northern Sweden because of the high latitude, but in practice nocturnal mist and midday heat haze sometimes prevented sampling. In 2004 we used 4x Thompson UGO night-vision binoculars to make nocturnal observations at the hide at the Legay pond in Marais Vernier. At Vinnö the lack of a permanent 
hide precluded a close enough approach to the birds to record their nocturnal behavior without disturbing them. In contrast to Marais Vernier, ducks at the spring staging sites Norvik and Vinnö stayed on the same wetlands $24 \mathrm{~h}$ a day.

Twenty-four-hour scan surveys were done weekly at Marais Vernier, Norvik, and Brånsjön Lake and twice a week at Vinnö. In Västerbotten, each oligotrophic breeding lake was visited for $2 \mathrm{~h}$ every 2 weeks instead of on a 24-h basis. Only one or two pairs of Teal bred on each of these lakes, sometimes making it difficult to observe the birds. To increase the chances of obtaining a sample, the frequency of scans was doubled to four scans every $2 \mathrm{~h}$ instead of one per hour as in all other regions. Behavioral data were thus collected throughout the day with an interval of at least a half an hour, but generally $1 \mathrm{~h}$, between two samples. This was done to avoid always collecting data at the same time of day, which could possibly bias the results (e.g., motionless birds may become under-recorded when light conditions deteriorate; cf. Paulus 1982; Baldassarre et al. 1988). We randomly chose which time of day a breeding lake was sampled, but because of their number and the distance between them it was impossible to visit all on the same day. In the analyses of the oligotrophic breeding lakes we therefore consider data from a "sampling session", i.e., 2 or more days, as being from the same "study day".

The total density of dabbling ducks (all Anas species and including ducklings) was calculated for each scan sample. Whenever possible, we recorded the sex of each duck. Molt begins at the end of June in the breeding area studied (Sjöberg 1986), and most males wore eclipse plumage in July. This, together with bad weather or light conditions, sometimes made it impossible to sex a bird. Individuals of unknown sex were not used in the statistical analysis of sexual differences in behavior.

We recorded the behavior of each bird observed during a scan sample and classed the behavior as foraging if the bird was performing any of seven foraging behaviors: grazing, catching flying insects, bill under water, head under water, neck under water, up-ending, and diving (the latter being very rare except during molt). Though ducklings were included when analyzing the effect of duck density, only adults were considered in the behavioral samples.

Predator disturbance possibly affecting the ducks (i.e., forcing some or all to take flight) was recorded throughout each study day and subsequently expressed as frequency (the average number of disturbance events per hour). Predators were both avian (Marsh Harrier (Circus aeruginosus (L., 1758)), Common Buzzard (Buteo buteo (L., 1758)), Osprey (Pandion haliaetus (L., 1758)), Red Kite (Milvus milvus (L., 1758)), Peregrine Falcon (Falco peregrinus Tunstall, 1771), Hooded Crow (Corvus corone cornix L., 1758), Common Raven (Corvus corax L., 1758), owl (Asio sp.), and White-tailed Eagle (Haliaeetus albicilla (L., 1758))) and mammalian (red fox (Vulpes vulpes (L., 1758))).

\section{Analyses}

For our analyses we divided the year into four seasons, early spring migration (February and March), late spring migration (April and May), breeding (June and July), and molt (August), and the day into two periods, night (1800-0600 Coordinated Universal Time (UTC)) and day (0600-1800
UTC). When analyzing diel patterns we averaged the proportion of ducks foraging during each period of each day, excluding days for which only diurnal or only nocturnal data were available. Note that in 2003 we did not sample at night during the early spring migration season, nor during fall migration. Preliminary analyses revealed no difference between years and therefore data from the 2 years were combined.

We used Spearman's rank correlation (Statistica ${ }^{\circledR}$; Statsoft Inc. 2002) to assess potential changes in the daily proportion of time spent foraging over time within each season and in each region, as well as for assessing the behavioral response to disturbance, to Teal density, and to the density of other dabbling ducks. The overall differences between years, seasons, period of the day and region were assessed with GLMs (Statistica ${ }^{\circledR}$; Statsoft Inc. 2002). Proportions were arcsine square root transformed prior to the latter analyses (Sokal and Rohlf 1995).

\section{Results}

\section{Diel patterns and seasonal changes}

A GLM model testing for differences among seasons and periods of the day and the effect of their interaction in explaining the proportion of time Teal spent foraging fitted the data significantly (full model: $F_{[7,109]}=10.2, P<$ $0.0001)$. The proportion of time spent foraging varied significantly among seasons $\left(F_{[3,109]}=5.4, P=0.002\right.$; Fig. 1$)$, but not among periods of the day $\left(F_{[1,109]}=3.7, P=0.059\right)$, while the season $\times$ period of the day interaction had a significant effect $\left(F_{[3,109]}=8.4, P<0.0001\right)$. Post hoc Bonferroni $t$ tests at $P<0.05$ revealed that this was essentially due to the fact that diurnal foraging time of Teal during the early spring migration was dramatically shorter than either diurnal or nocturnal foraging during any other season. The only exception was diurnal foraging time during molting, which was at a comparable level.

Diurnal foraging time decreased over time during late spring migration $\left(r_{\mathrm{S}}=-0.79, P<0.0001, N=22\right)$. Nocturnal foraging time also decreased over time during late spring migration $\left(r_{\mathrm{S}}=-0.51, P=0.02, N=20\right)$. When considering data from early in the breeding period are considered, i.e., broadly from early June to early July at Brånsjön Lake, the correlation was highly significantly positive for nocturnal foraging time $\left(r_{\mathrm{S}}=0.89, P=0.001, N=9\right)$ as well as diurnal foraging time $\left(r_{\mathrm{S}}=0.781, P=0.008, N=10\right.$; Fig. 2$)$.

\section{Intersexual differences in Teal}

Using data on sexed birds, we tested whether average foraging time varied among seasons or between the sexes, and whether their interaction had a significant effect. The full models fitted the data significantly for diurnal foraging and daily average foraging time (Table 2) but not for nocturnal foraging $\left(F_{[5,82]}=0.6, P=0.690\right)$. However, in all cases this was only due to the differences between seasons (Table 2), bringing us back to the smaller proportion of time spent foraging during the early spring migration period.

We then tested whether foraging time differed between the sexes or periods of the day and if the sex $\times$ period of the day interaction had a significant effect. We only used data from the days for which both diurnal and nocturnal 
Fig. 1. Daily proportion of time (mean \pm SE) spent foraging by Eurasian Green-winged Teal (Anas crecca crecca; solid bars), Mallard (Anas platyrhynchos; open bars), and Northern Shoveler (Anas clypeata; hatched bars) during daytime (0600-1800) (a) and nighttime (1800-0600) (b) per season and per year.
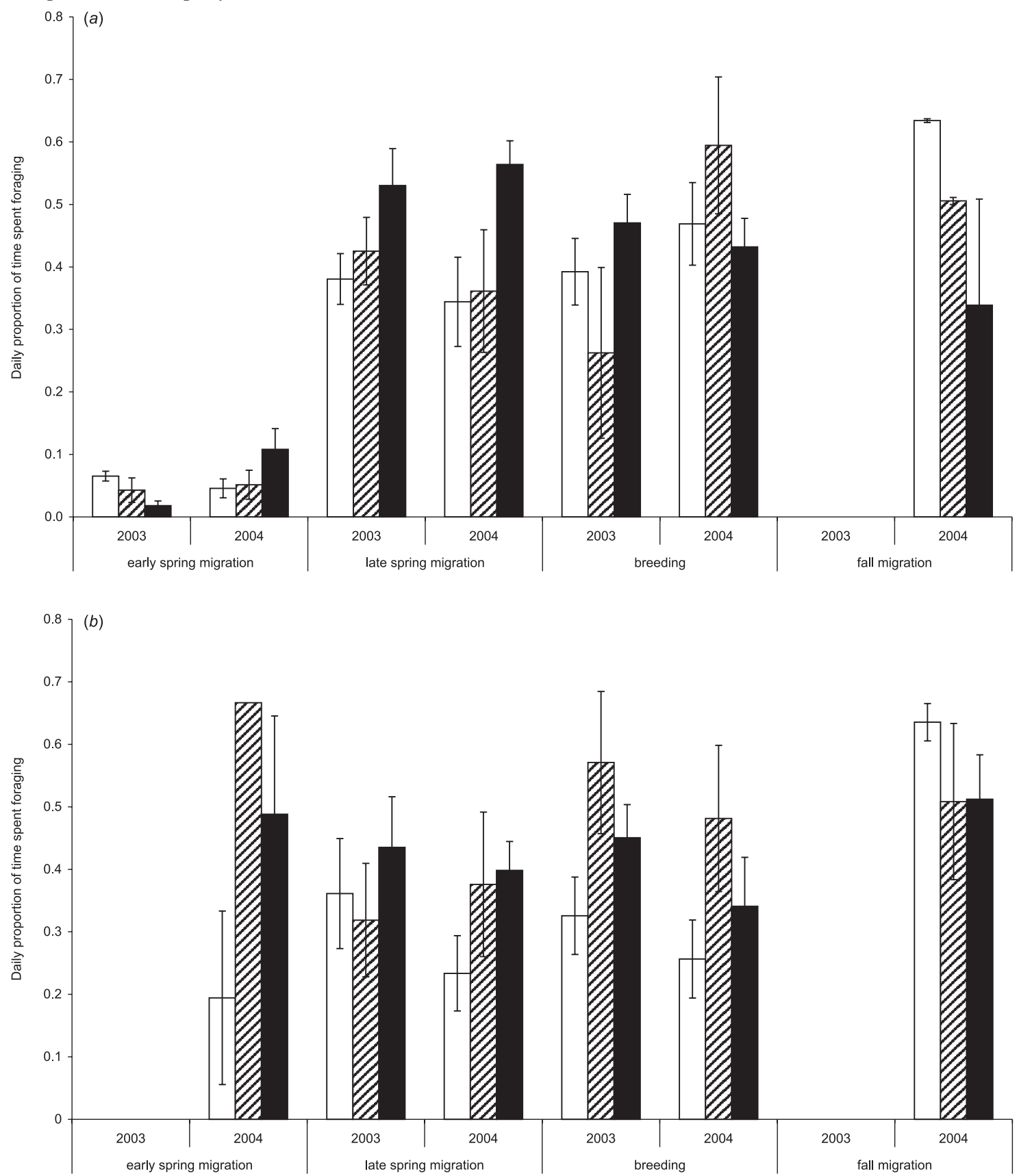

data were available. The full model did not fit the data significantly $\left(F_{[3,166]}=0.5, P=0.72\right)$; irrespective of sex and time of the day, Teal spent $44.7 \% \pm 2.0 \%$ (mean $\pm \mathrm{SE} ; N=$ 170) of $12 \mathrm{~h}$ periods foraging.

\section{Differences among duck species}

Time spent foraging was similar among species (Fig. 1, Table 3) and, on average, the three species spent $34 \% \pm$ $1.9 \%$ (mean $\pm \mathrm{SE} ; N=180$ ) of daylight hours foraging. All species spent less diurnal time foraging during early spring migration than during all other periods. During molt there was a general but nonsignificant increase in nocturnal for- aging time for Teal, Mallard, and Shoveler (Fig. 1b). Nocturnal foraging time did not vary among species $\left(F_{[11,117]}=1.5, P=0.15\right)$.

When considering the dates for which both nocturnal and diurnal data were available, the full model fitted the data (Table 3), but only season, not species, had a significant effect. Post hoc Bonferroni $t$ tests at $P<0.05$ showed that the difference was due to a larger share of time allocated to foraging during molt than during early spring migration.

\section{Effect of disturbance}

In Mallard and Shoveler, neither diurnal nor nocturnal 
Fig. 2. Daily proportion (mean \pm SE) of time spent foraging by Teal in each period of the day and season in 2003 and 2004 . Diurnal data (solid bars) were collected between 0600 and 1800 and nocturnal data (open bars) between 1800 and 0600.

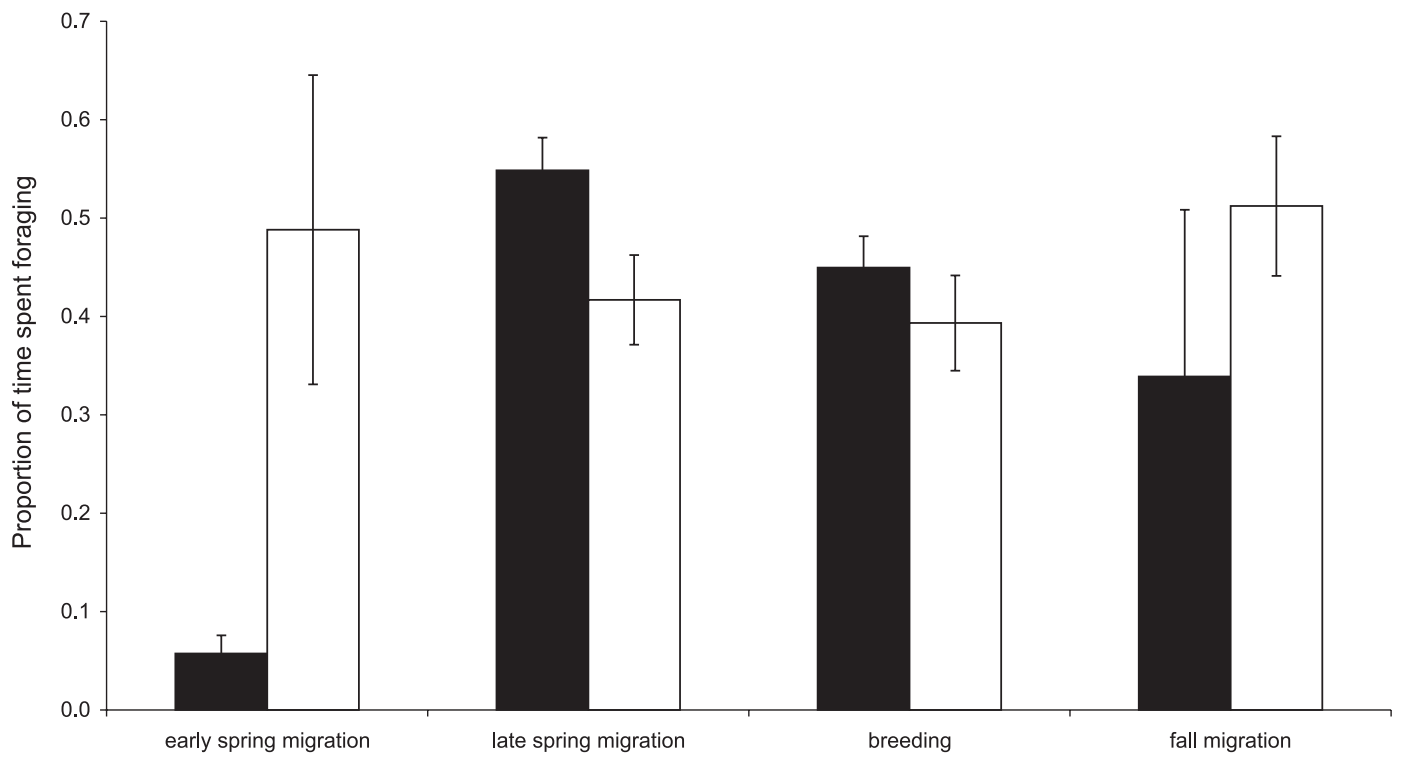

Table 2. GLM exploring variation in diurnal and daily average foraging time among seasons and sexes.

\begin{tabular}{llrll}
\hline & & $F$ & df & $P$ \\
\hline Diurnal foraging & Full model & 20.524 & 5,114 & $<0.0001$ \\
& Season & 50.722 & 2,114 & $<0.0001$ \\
& Sex & 0.249 & 1,114 & 0.619 \\
& Season $\times$ sex & 0.651 & 2,114 & 0.524 \\
Daily average & Full model & 2.329 & 5,80 & 0.050 \\
& Season & 4.178 & 2,118 & 0.0188 \\
& Sex & 0.008 & 1,80 & 0.928 \\
& Season $\times$ sex & 1.440 & 2,80 & 0.243 \\
\hline
\end{tabular}

Table 3. GLM exploring variation in the average proportion of time spent foraging among species and seasons.

\begin{tabular}{llrrl}
\hline & & \multicolumn{1}{l}{ df } & \multicolumn{1}{l}{$P$} \\
\hline Diurnal foraging & Full model & 12.445 & 11,168 & $<0.001$ \\
& Season & 40.440 & 3,168 & $<0.0001$ \\
& Species & 0.255 & 2,168 & 0.775 \\
Average & Season $\times$ species & 1.793 & 6,168 & 0.103 \\
& Full model & 1.950 & 11,115 & 0.040 \\
& Season & 2.721 & 3,115 & 0.048 \\
& Species & 0.322 & 2,115 & 0.725 \\
& Season $\times$ species & 1.101 & 6,115 & 0.366 \\
\hline
\end{tabular}

foraging time was significantly correlated with the frequency of disturbance by predators. In Teal, average diurnal foraging time, but not nocturnal foraging time, increased significantly with decreasing predator disturbance (Table 4).

There was a temporal pattern of decreasing predator disturbance from early spring through the breeding season $\left(r_{\mathrm{S}}=-0.48, P<0.0001, N=67\right.$; Fig. 3$)$ for daytime data but not for nighttime data $\left(r_{\mathrm{S}}=-0.04\right.$, ns, $N=50$; Fig. 3$)$.

\section{Effect of duck density}

A GLM revealed a significant effect of season, year, and
Table 4. Spearman's rank correlations between the species-specific average diurnal (1800-0600) and nocturnal (0600-1800) proportions of time spent foraging and density of Teal, density of all dabbling ducks (Teal included), and frequency of disturbance by predators.

\begin{tabular}{|c|c|c|c|c|c|}
\hline & $\begin{array}{l}\text { Period of } \\
\text { the day }\end{array}$ & $\begin{array}{l}\text { Relation } \\
\text { tested }\end{array}$ & $N$ & $r_{\mathrm{S}}$ & $P$ \\
\hline \multirow[t]{6}{*}{ Mallard } & \multirow[t]{3}{*}{ Daytime } & Teal density & 67 & 0.066 & ns \\
\hline & & Duck density & 67 & -0.070 & $\mathrm{~ns}$ \\
\hline & & Disturbance & 67 & -0.151 & ns \\
\hline & \multirow[t]{3}{*}{ Nighttime } & Teal density & 47 & 0.094 & ns \\
\hline & & Duck density & 47 & 0.077 & ns \\
\hline & & Disturbance & 47 & -0.157 & $\mathrm{~ns}$ \\
\hline \multirow[t]{6}{*}{ Shoveler } & \multirow[t]{3}{*}{ Daytime } & Teal density & 46 & -0.126 & $\mathrm{~ns}$ \\
\hline & & Duck density & 46 & -0.190 & $\mathrm{~ns}$ \\
\hline & & Disturbance & 46 & -0.250 & $\mathrm{~ns}$ \\
\hline & \multirow[t]{3}{*}{ Nighttime } & Teal density & 32 & 0.271 & ns \\
\hline & & Duck density & 32 & 0.270 & $\mathrm{~ns}$ \\
\hline & & Disturbance & 32 & -0.221 & $\mathrm{~ns}$ \\
\hline \multirow[t]{6}{*}{ Teal } & \multirow[t]{3}{*}{ Daytime } & Teal density & 66 & 0.276 & 0.024 \\
\hline & & Duck density & 66 & 0.124 & ns \\
\hline & & Disturbance & 66 & -0.264 & 0.031 \\
\hline & \multirow[t]{3}{*}{ Nighttime } & Teal density & 50 & 0.419 & 0.002 \\
\hline & & Duck density & 50 & 0.441 & 0.001 \\
\hline & & Disturbance & 50 & -0.276 & ns \\
\hline
\end{tabular}

Note: ns, not significant.

their interaction on Teal diurnal density (full model: $F_{[5,58]}=$ 10.0, $P<0.0001$; season: $F_{[2,58]}=8.9, P=0.0004$; year: $F_{[1,58]}=8.4, P=0.0054$; interaction: $F_{[2,58]}=9.6, P=$ 0.0002 ). However, post hoc Bonferroni $t$ tests at $P<0.05$ showed that this was entirely due to differences between data from late spring migration in 2004 and the other data (Fig. 4). Diurnal foraging time for Teal was positively correlated with intraspecific density but not with that of all dabbling ducks (Table 4).

Again there was a significant effect of year, season, and their interaction on the nocturnal density of Teal (full 
Fig. 3. Frequency (mean \pm SE) of diurnal (0600-1800; solid bars) and nocturnal (1800-0600; open bars) disturbance events per hour in each season and year.

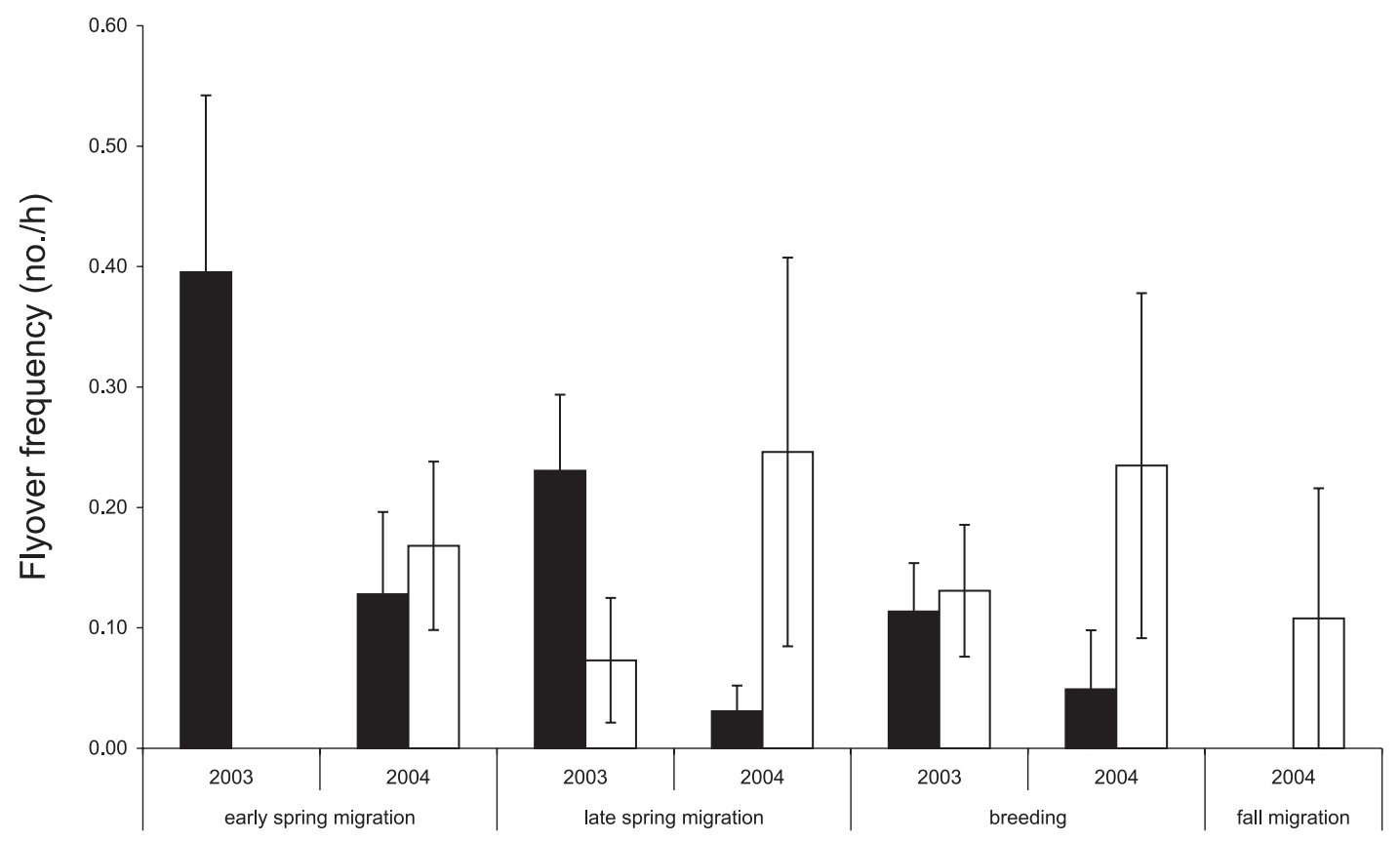

model: $F_{[3,39]}=10.1, P=0.0004$; season: $F_{[1,39]}=9.7, P=$ 0.004 ; year: $F_{[3,39]}=9.8, P=0.003$; interaction: $F_{[3,39]}=$ $12.3, P=0.001$; note that as before, only data from late spring migration and breeding period were used in this analysis) and the nocturnal density of all ducks present on the site $\left(F_{[3,39]}=4.3, P=0.01\right)$. Post hoc Bonferoni $t$ tests at $P<0.05$ revealed that during the late spring migration period in 2004 the density of ducks was far higher than in any other period in 2003 and 2004. When the whole data set (Fig. $4 b$ ) is considered, it is also clear that during early spring migration the density of birds was quite high at the nocturnal foraging site in Marais Vernier. This was essentially due to a large number of Teal aggregating on the small Legay pond at dawn; they were foraging there the whole night and flew away at sunrise.

Nocturnal foraging time spent by Teal was also positively correlated with intraspecific density. In contrast to diurnal data, however, nocturnal foraging time was also significantly correlated with the combined density of all ducks species present (Table 4). Note that among the ducks observed on the different sites, Teal was the most abundant species most of the time, consequently the density of ducks might to some extent be related to that of Teal.

\section{Discussion}

The present study is quite unique in the sense that the same standardized method was employed all along the flyway and that only one observer performed all behavioral recordings, thus avoiding many possible biases. We call for more studies employing the same methodology at other locations along the flyway to further explore possible changes in time allocated to foraging, especially during the last weeks before breeding.

\section{Foraging activity over time}

Daily foraging time varies significantly over the year in many Anatidae (i.e., diving and dabbling ducks, geese, and swans). The general pattern is that time spent foraging is highest in fall, declines in midwinter, and increases in early spring (Paulus 1988; Tamisier et al. 1995). Our finding that over the study period, Teal spent, on average, $87.5 \%$ of the $24 \mathrm{~h}$ foraging suggests that foraging time increases in spring and summer compared with the winter average of $45.8 \%$ reported by Tamisier and Dehorter (1999). Foraging needs generally increase before or during costly activities such as migration, breeding, and molt (King 1974; Ricklefs 1974). By and large, the observed changes in foraging time in the present study corroborate this view. Indeed, Teal, Mallard, and Shoveler spent less time foraging in early spring than later in migration and during the breeding and molting seasons. Teal foraging time peaked during late spring migration at stopover sites, and then decreased slightly after arrival on still largely ice-covered breeding grounds. The same general pattern was observed in Mallard and Shoveler. The largest difference among the species was observed during molt, when foraging time was at its maximum in Mallard but not in Teal and Shoveler. Species-specific requirements and differences in the timing of breeding, molt, and migration may explain these differences (cf. Cramp and Simmons 1977).

Exogenous resources and nutrient reserves are essential to income-breeding and income-migrating (sensu Arzel 2006) waterfowl (Vangilder et al. 1986; Bromley and Jarvis 1993; Klaassen 2002). In geese it has been demonstrated that deposition of reserves prior to migration is made possible partly by increasing food-assimilation efficiency and partly by reducing energy use for normal activities, but principally by increasing food intake, also called hyperphagia (e.g., Madsen 1995). The latter and the associated accumulation of 
Fig. 4. Diurnal $(a)$ and nocturnal $(b)$ daily on-site density (number of birds per hectare; mean \pm SE) of Teal (solid bars) and all dabbling ducks (open bars) in each season and year.
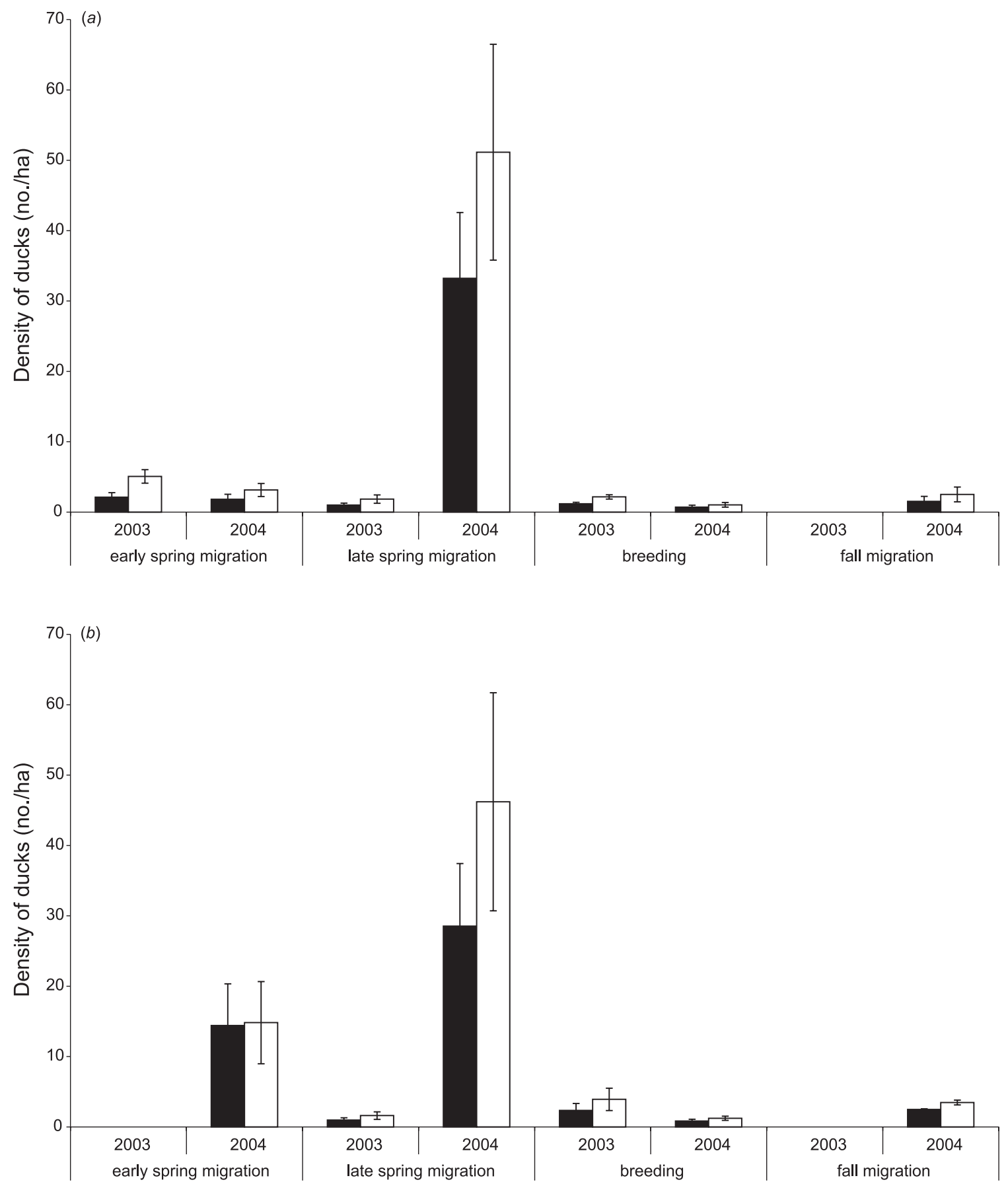

body reserves occur some weeks prior to departure for the breeding grounds (McLandress and Raveling 1981; Gauthier et al. 1992). In early spring in the present study (February and March), ducks were foraging almost exclusively at night, but they also had the lowest total daily foraging time. A dramatic increase took place later on, at stopover areas in southern Sweden, allowing us to suppose that Teal, Mallard, and Shoveler fuel their migration by means of exogenous reserves they find en route, and that they may not increase body reserves very much prior to initial departure. Another result corroborating such a view is the increase of foraging time during the breeding period in both years, which may have been a response to higher energy needs resulting from to breeding activities. This, along with the observed decrease of foraging time from the birds' arrival to their departure from the late spring staging sites, is consistent with the fact that fat is not always beneficial to carry, especially in small species, since it may increase predation risk by reducing maneuverability and the ability to take off quickly (Lima 1986; Witter and Cuthill 1993). In terms of changes in foraging time over the seasons, the present study provides the first behavior-based corroboration of the theoretical prediction 
that dabbling ducks will, given their small size, be more like income breeders than capital breeders (Klaassen 2002).

The proportion of time spent foraging during the night (i.e., from 1800 to 0600 ) did not vary over the seasons covered by the present study, and remained very high throughout. This was in contrast to the diurnal proportion of time spent foraging, which increased a lot over the same period.

Marais Vernier is the only region where we found a pronounced diel difference between nocturnal and diurnal foraging times, matching the results obtained earlier on wintering areas (Paulus 1988; Tamisier and Dehorter 1999; Guillemain et al. 2002). In all other regions the proportions of time spent foraging were fairly similar in night- and daytime, while the average daily foraging time was longer, indicating that when Teal had to increase foraging time, they did so in daytime. This response concurs with earlier winter studies showing that though the proportion of nocturnal foraging is rather constant, dabbling ducks in colder areas (and hence having higher energy needs) compensate by increasing foraging time during daylight hours (Tamisier and Dehorter 1999; Guillemain et al. 2002).

\section{Intrasexual differences}

Female Mallards are known to feed more than their mates during the breeding season (Asplund 1981; Batt et al. 1992; Arzel and Elmberg 2004), a pattern supposedly linked to the costs of egg formation and relative fasting during brooding. We cannot offer any obvious explanation why male and female Teal in the present study spent equal time foraging, "a negative result" that applies to migrating as well as breeding birds. The same goes for the observed lack of difference in diel allocation of foraging time between males and females. A possible explanation is that in small species, especially income breeders, individuals of both sexes need to forage all along the flyway to meet their nutritional requirements.

\section{Biotic factors}

Waterfowl are known to be highly sensitive to disturbance (Madsen 1995), which may impose high energy costs due to escape flights (Madsen 1998) and also force birds to allocate more time to vigilance at the expense of foraging (Fox et al. 1993; Riddington et al. 1996). Disturbance studies so far have mainly been carried out on wintering grounds, in fall stopover areas, and on breeding grounds (Pöysä 1987; Fritz et al. 2000; Lank et al. 2003). However, the effects of disturbance on spring-staging and prebreeding ducks remain largely undocumented (but see Skyllberg et al. 2005). Diurnal avian predators appear to be the main source of non-human disturbance to dabbling ducks in winter (Fritz et al. 2000). In this study we also considered terrestrial predators (which, however, caused a small proportion of the disturbance events compared with avian predators), and it turned out that total predator disturbance frequency decreased with increasing latitude within the flyway. We show that this was associated with more time spent foraging by Teal but not by Shoveler and Mallard. A companion study (Guillemain et al. 2007) also shows that Teal tend to rely more on riskier underwater foraging methods when moving north, supposedly because of this amelioration of the predation risk.

Density-dependent effects on waterfowl behavior have been studied on breeding grounds (Mjelstad and Saetersdal 1988) as well as on wintering grounds (Pettifor et al. 2000), but never at spring staging areas. In winter, dabbling ducks are known to aggregate in large flocks during the day (Tamisier 1972), whereas on the breeding grounds they space out on countless lakes and wetlands. In the landscape context, Teal density in the boreal zone is frequently so low that a large proportion of lakes do not have any breeding pairs (Elmberg et al. 2005). Peak density of Teal and other dabbling ducks in the present study occurred at night during early spring migration and in April at the mid-flyway staging sites. Contrary to expectations, within the paradigm of density-dependence, we observed a significant positive relationship between Teal foraging time and intraspecfic as well as intraguild density. It should be noted that duck density differed a lot between the two April study sites, yet no difference in foraging time was observed. This positive correlation may simply reflect the concurrent increase in foraging time linked to higher nutritional requirements and the concentration of birds on highly attractive stopover areas where food resources are not limiting, though limited. The fact that many birds are present together at a location may also have beneficial effects, for example in terms of time allocated to vigilance instead of foraging.

There are earlier studies of avian time budgets from wintering or breeding grounds, but to our knowledge this is the first time foraging data for a long-distance migrant have been collected with standardized methods throughout the flyway. In addition to demonstrating some marked differences in foraging behavior among regions and seasons, our study also has some management implications. Foraging time increased dramatically during migration, as documented by data from mid-flyway staging sites, highlighting the need for adequate management of such wetlands. The increase in daily foraging time was manifested as a higher proportion of time spent foraging during daylight hours over the seasons, while nocturnal foraging time remained at the same level. The change in diurnal foraging time could not be linked to concomitant changes in intraspecific or intraguild population density, which lets us suppose that the carrying capacity of the study sites was probably not reached at the time of this study. Based on the fact that dabbling ducks, especially teals, increase their foraging activity at times of high energy requirements, we suggest that they are both income breeders and "income migrants". This highlights the importance of stopover availability and suitability along their flyway, especially the need for sites with high food availability and low disturbance. To better understand the ecology of medium- and long-distance migrants, further studies based on circumannual approaches need to be undertaken.

\section{Acknowledgments}

We sincerely thank the two anonymous reviewers, whose comments greatly improved the manuscript. We are extremely grateful to Christer Olsson for initially locating likely breeding lakes for Teal in Västerbotten. We thank the county administration board of Västerbotten and the Ottenby Bird Observatory for access to the reserves at Brånsjön and Norvik, respectively. The owners of Vinnö Ängar generously let us use their wetlands. We also thank the staff at the Department of Wildlife Ecology at the Swedish Univer- 
sity of Agricultural Sciences in Umeå, especially Kjell Sjöberg, Kjell Danell, and Joakim Hjältén. We sincerely thank Raoul Legay for permitting us to work on his hunting pond and even more for using his hunting hide. We are grateful to Thierry Lecomte and Luc Tison for helping us in Normandy. This work was supported by grants V-162-05, V-124-01, and V-98-04 from the Swedish Environmental Protection Agency to Johan Elmberg, and by a Ph.D. grant from Office National de la Chasse et de la Faune Sauvage to Céline Arzel.

\section{References}

Alisauskas, R.T., and Ankney, C.D. 1994. Nutrition of breeding female ruddy ducks: the role of nutrient reserves. Condor, 96: 878-897.

Altmann, J. 1974. Observational study of behaviour: sampling methods. Behaviour, 49: 227-267. PMID:4597405.

Arzel, C. 2006. Ecology of teals and other dabbling ducks: connection between their wintering, spring staging and breeding grounds. Ph.D. thesis, Toulouse III University, Toulouse, France.

Arzel, C., and Elmberg, J. 2004. Time use, foraging behaviour and microhabitat use in a temporary guild of spring staging dabbling ducks (Anas spp.). Ornis Fenn. 81: 157-168.

Arzel, C., Elmberg, J., and Guillemain, M. 2006. Ecology of spring-migrating Anatidae: a review. J. Ornithol. 147: 167-184. doi:10.1007/s10336-006-0054-8.

Asplund, C. 1981. Time budgets of breeding Mallard in northern Sweden. Wildfowl, 32: 55-64.

Åström, M. 1992. Interspecific variation in time budgets among sympatric dabbling ducks. Ornis Svec. 2: 131-138.

Bakken, V., Runde, O., and Tjørve, E. 2003. Norwegian bird ringing atlas. Stavanger Museum, Stavanger, Norway.

Baldassarre, G.A., Paulus, S.L., Tamisier, A., and Titman, R. 1988 Workshop summary: techniques for timing activity of wintering waterfowl. In Waterfowl in winter. Edited by M.W. Weller. University of Minnesota Press, Minneapolis. pp. 181-188.

Batt, B.D.J., Afton, A.D., Anderson, M.G., Ankney, C.D., Johnson, D.H., Kadlec, J.A., and Krapu, G.L. (Editors). 1992. Ecology and management of breeding waterfowl. University of Minnesota Press, Minneapolis.

Bromley, R.G., and Jarvis, R.L. 1993. The energetics of migration and reproduction of Dusky Canada Geese. Condor, 95: 193-210.

Clairefond, P., and Schricke, V. 1994. Gestion de la réserve de chasse et de faune sauvage de la Grand'Mare. Bull. Office National de la Chasse, 189(Spec. Issue): 46-49.

Cramp, S., and Simmons, K.E.L. 1977. Birds of the Western Palearctic. Vol. 1. Oxford University Press, Oxford.

Danell, K., and Sjöberg, K. 1979. Abundance and productivity of ducks on boreal lakes in northern Sweden. Ann. Zool. Fenn. 16: 123-128.

Ebbinge, B.S., and Spaans, B. 1995. The importance of body reserves accumulated in spring staging areas in the temperate zone for breeding in Dark-bellied Brent Geese Branta b. bernicla in the high Arctic. J. Avian Biol. 26: 105-113.

Elmberg, J., Nummi, P., Pöysä, H., Gunnarsson, G., and Sjöberg, K. 2005. Early breeders use the best lakes and have higher reproductive success in Teal Anas crecca. Ann. Zool. Fenn. 42: 37-43.

Fox, A.D., Bell, D.V., and Mudge, G.P. 1993. A preliminary study of the effects of disturbance on feeding wigeon grazing on eelgrass Zostera. Wader Study Group Bull. 68(Spec. Issue): 67-71.

Fransson, T., and Pettersson, J. 2001. Swedish bird ringing atlas.
Vol. 1. Divers-raptors. The Swedish Museum of Natural History, Stockholm.

Fritz, H., Guillemain, M., and Guérin, S. 2000. Changes in the frequency of prospecting fly-overs by marsh harriers (Circus aeruginosus) in relation to short-term fluctuations in dabbling ducks abundance. Ardea, 88: 9-16.

Gauthier, G., Giroux, J.F., and Bédard, J. 1992. Dynamics of fat and protein reserves during winter and spring migration in Greater Snow Geese. Can. J. Zool. 70: 2077-2087.

Guillemain, M., Fritz, H., and Duncan, P. 2002. Foraging strategies of granivorous dabbling ducks wintering in protected areas of the French Atlantic coast. Biodiversity Conserv. 11: 1721-1732. doi:10.1023/A:1020322032114.

Guillemain, M., Fritz, H., Klaassen, M., Johnson, A.R., and Hafner, H. 2004. Fuelling rates of Garganey (Anas querquedula) staging in the Camargue, southern France, during spring migration. J. Ornithol. 145: 152-158. doi:10.1007/s10336-004-0026-9.

Guillemain, M., Arzel, C., Mondain-Monval, J.Y., Schricke, V., Johnson, A.R., and Simon, G. 2006. Spring migration dates of Teal ringed in the Camargue, southern France. Wildl. Biol. 12: 163-169.

Guillemain, M., Arzel, C., Legagneux, P., Elmberg, J., Fritz, H., Lepley, M., Pin, C., Arnaud, A., and Massez, G. 2007. Teal (Anas crecca) adjust foraging depth to predation risk: a flywaylevel circum-annual approach. Anim. Behav. In press.

Hickey, T.E., and Titman, R.D. 1983. Diurnal activity budgets of black ducks during their annual cycle in Prince Edward Island. Can. J. Zool. 61: 743-749.

King, J.R. 1974. Seasonal allocation of time and energy resources in birds. In Avian energetics. Vol. 15. Edited by R.A. Paynter. Nuttall Ornithol. Club, Cambridge, Mass. pp. 4-70.

Klaassen, M. 2002. Relationships between migration and breeding strategies in arctic breeding birds. In Avian migration. Edited by P. Berthold, E. Gwinner, and E. Sonnenschein. Springer-Verlag, Berlin. pp. 237-249.

Koskimies, J. 1956. Heinäsorsakantamme verotus meillä ja muualla. [Harvest of our Mallard population here and abroad.] Suom. Riista, 10: 18-25.

Lank, D.B., Butler, R.W., Ireland, J., and Ydenberg, R.C. 2003. Effects of predation danger on migration strategies of sandpipers. Oikos, 103: 303-319. doi:10.1034/j.1600-0706.2003.12314.x.

Lima, S.L. 1986. Predation risk and unpredictable feeding conditions: determinants of body mass in birds. Ecology, 67: 377385. doi:10.2307/1938580.

Lindberg, M.S., Sedinger, J.S., and Flint, P.L. 1997. Effects of spring environment on nesting phenology and clutch size of Black Brant. Condor, 99: 381-388.

Madsen, J. 1995. Impacts of disturbance on migratory waterfowl. Ibis, 137: S67-S74.

Madsen, J. 1998. Experimental refuge for migratory waterfowl in Danish wetlands. I. Baseline assessment of the disturbance effects of recreational activities. J. Appl. Ecol. 35: 386-397. doi:10.1046/j.1365-2664.1998.00314.x.

McLandress, M.R., and Raveling, D.G. 1981. Hyperphagia and social behavior of Canada Geese prior to spring migration. Wilson Bull. 93: 310-324.

Miller, M.R. 1985. Time budgets of Northern Pintails wintering in the Sacramento Valley, California. Wildfowl, 36: 53-64.

Mjelstad, H., and Saetersdal, M. 1988. The effects of density on time budget of breeding Mallards Anas platyrhynchos. Fauna Norv. Ser. C Cinclus, 11: 11-18.

Morton, J.M., Fowler, A.C., and Kirkpatrick, R.L. 1989. Time and energy budgets of American black ducks in winter. J. Wildl. Manag. 53: 401-410. 
Paquette, G.A., and Ankney, C.D. 1998. Diurnal time budgets of American Green winged Teal Anas crecca breeding in British Columbia. Wildfowl, 49: 186-193.

Paulus, S.L. 1982. Feeding ecology of gadwalls in Louisiana in winter. J. Wildl. Manag. 46: 71-79.

Paulus, S.L. 1988. Time-activity budgets of non breeding Anatidae: a review. In Waterfowl in winter. Edited by M.W. Weller. The University of Minnesota Press, Minneapolis. pp. 135-152.

Pettifor, R.A., Caldow, R.W.G., Rowcliffe, J.M., Goss-Custard, J.D., Black, J.M., Hodder, K.H., Houston, A.I., Lang, A., and Webb, J. 2000. Spatially explicit, individual-based, behavioural models of the annual cycle of two migratory goose populations. J. Appl. Ecol. 37(Suppl. 1): 103-135. doi:10.1046/j.1365-2664. 2000.00536.x.

Pöysä, H. 1987. Costs and benefits of group foraging in the Teal (Anas crecca). Behaviour, 103: 123-140.

Ricklefs, R.E. 1974. Energetics of reproduction in birds. In Avian energetics. Vol. 15. Edited by R.A. Paynter. Nuttall Ornithol Club, Cambridge, Mass. pp. 152-297.

Riddington, R., Hassal, M., Lane, S.J., Turner, P.A., and Walters, R. 1996. The impact of disturbance on the behaviour and energy budgets of Brent Geese Branta bernicla. Bird Study, 43: 269279.

Scott, D.A., and Rose, P.M. 1996. Atlas of Anatidae populations in Africa and Western Eurasia. Wetlands International Publication 41. Wetlands International, Wageningen, the Netherlands.

Seymour, N.R. 1974. Territorial behaviour of wild shovelers at Delta, Manitoba. Wildfowl, 25: 49-55.

Sjöberg, K. 1986. The flightless period of free-living male Teal Anas crecca in northern Sweden. Ibis, 130: 164-171.

Skyllberg, U., Hansson, P., Bernhardtson, P., and Naudot, E. 2005. The roost-feeding area complex of Taiga Bean Goose Anser $f$. fabalis in the Ume River Delta Plains, Sweden - foraging patterns in comparison with Greylag Goose Anser anser, Whooper Swan Cygnus cygnus and Eurasian Crane Grus grus. Ornis Svec. 15: $73-88$.
Sokal, R.R., and Rohlf, F.J. 1995. Biometry. 3rd ed. W.H. Freeman and Co., New York.

Solonen, T. 1985. Suomen linnusto. [Bird fauna of Finland.] Lintutieto, Helsinki.

Statsoft Inc. 2002. Statistica ${ }^{\circledR}$ : prise en main. Statsoft Inc., Tulsa, Okla.

Stillman, R.A., Goss-Custard, J.D., West, A.D., Le, V., Dit Durell, S.E.A., Caldow, R.W.G., McGrorty, S., and Clarke, R.T. 2000. Predicting mortality in novel environments: tests and sensitivity of a behaviour-based model. J. Appl. Ecol. 37: 564-588. doi:10. 1046/j.1365-2664.2000.00506.x.

Sutherland, W.J., and Gosling, L.M. 2000. Advances in the study of behaviour and their role in conservation. In Behaviour and conservation. Edited by L.M. Gosling and W.J. Sutherland. Cambridge University Press, Cambridge. pp. 3-9.

Tamisier, A. 1972. Rythmes nycthéméraux des sarcelles d'hiver pendant leur hivernage en Camargue. Alauda, 2: 107-256.

Tamisier, A., and Dehorter, O. 1999. Camargue. Canards et foulques. Centre Ornithologique du Gard, Nîmes, France.

Tamisier, A., Allouche, L., Aubry, F., and Dehorter, O. 1995. Wintering strategies and breeding success: hypothesis for a trade-off in some waterfowl species. Wildfowl, 46: 76-88.

Teunissen, W., Spaans, B., and Drent, R. 1985. Breeding success in Brent in relation to individual feeding opportunities during spring staging in the Wadden Sea. Ardea, 73: 109-119.

Thompson, R.G., and Raveling, D.G. 1987. Incubation behaviour of Emperor geese compared with other geese: interactions of predation, body size and energetics. Auk, 104: 707-716.

Vangilder, L.D., Smith, L.M., and Lawrence, R.K. 1986. Nutrient reserves of premigratory brant during spring. Auk, 103: 237-241.

Wernham, C.V., Toms, M.P., Marchant, J.H., Clark, J.A., Siriwardena, G.M., and Baillie, S.R. 2002. The migration atlas: movements of the birds of Britain and Ireland. T. and A.D. Poyser, London.

Witter, M.S., and Cuthill, I.C. 1993. The ecological costs of avian fat storage. Philos. Trans. R. Soc. Lond. B Biol. Sci. 340: 73-92. 